\title{
Jurnal
}

Manajemen Kesehatan Indonesia

Volume 7

Nomor 3

Desember 2019

\section{Supervisi dan Ketersediaan Buku KIA Terhadap Penggunaan Buku KIA oleh Bidan Desa}

\author{
Muhdar*, Cahya Tri Purnami**, Titi Suherni** \\ * Program Studi D3 Keperawatan Universitas Sembilanbelas November Kolaka \\ **Program Studi Ilmu Kesehatan Masyarakat Universitas Diponegoro
}

\section{ABSTRACT}

The high MMR of the government issued a Minister of Health Decree on the $\mathrm{MCH}$ Handbook, stating that the $\mathrm{MCH}$ Handbook is a tool for early detection of disorders or health problems for mothers and children. The purpose of this research is to determine the perception of supervision and availability of MCH books influencing the use of MCH books. Research method was observational quantitative research with cross sectional study. Research samples were the 55 village midwife with simple random sampling technique. Research analysis was Moment and Sperman's rho product analysis, and multivariate analysis with linear regression test. Based on the research, perception variables with Pearson's $R$. correlation test obtained $r=$ 0.244 and $p=0.73$ where the value of $p>$ 0.05 means that there is no significant relationship between perception of supervision with the use of the $\mathrm{MCH}$ handbook. Variable availability of $\mathrm{MCH}$ books with the Spearman correlation test, Rho obtained $r=0.157$ and $p=0.25$ where $p>0.05$, which means there is no significant relationship between the availability of $\mathrm{MCH}$ books with the use of $\mathrm{MCH}$ books. The study found perception of supervision and provision of $\mathrm{MCH}$ books did not significantly influence the use of $\mathrm{MCH}$ books in antenatal services. Kolaka District Health Office needs to increase the role of periodic supervision and procurement of $\mathrm{MCH}$ books in accordance with the target number and availability of MCH books at health service sites.

Keywords: Supervision, availability, $M C H$ Book

\section{PENDAHULUAN}

Salah satu indikator keberhasilan upaya kesehatan ibu adalah angka kematian ibu, dimana kematian tersebut terjadi selama kehamilan, persalinan dan masa nifas, yang bukan disebabkan cedera atau kecelakaan. Selain untuk menilai program kesehatan ibu, indikator ini juga mampu menilai derajat kesehatan masyarakat, karena sensitivitasnya terhadap perbaikan pelayanan kesehatan, baik dari sisi aksesibilitas maupun kualitas. $^{1}$ Angka kematian ibu di Kabupaten Kolaka menunjukkan bahwa angka kematian ibu sangat fluktuatif. Dimana terjadi kenaikan pada tahun 2015 yaitu dari 114 menjadi 135 per 100.000 kelahiran hidup. Kemudian pada tahun 2016, kembali turun ke angka 117 per 100.000 kelahiran hidup, pada tahun 2017 kembali naik yang signifikan ke angka 137 
per 100.000 kelahiran hidup, dan pada tahun 2018 terus naik ke angka 165 per 100.000 kelahiran hidup. Pada tahun 2018, angka kematian ibu tertinggi dalam kurun waktu 5 tahun terakhir. Kematian ibu disebabkan oleh perdarahan dan penyebab lain. Kasus tersebut seharusnya dapat dideteksi sedini mungkin dengan pemeriksaan antenatal care dengan menggunakan buku KIA. Berdasarkan data yang diperoleh, angka cakupan K2 sebanyak $82 \%$, dimana belum memenuhi target $95 \%{ }^{2}$

Buku KIA merupakan alat untuk mendeteksi secara dini adanya gangguan atau masalah kesehatan ibu dan anak. Selain itu, buku KIA juga berperan sebagai alat komunikasi dan penyuluhan mengenai informasi yang penting bagi ibu dan keluarga dan masyarakat seperti pelayanan kesehatan ibu, anak, rujukan pelayanan KIA, gizi, imunisasi dan tumbuh kembang balita. Sehingga ketika buku KIA tidak dimanfaatkan dengan baik maka akan sulit melakukan deteksi sejak dini pada ibu dan anak. Buku KIA diberikan pada ibu pada saat pertama kali memeriksakan kehamilannya dan selanjutnya buku tersebut dibawa ibu untuk disimpan di rumah. Buku KIA yang diisi lengkap akan memudahkan bidan untuk mendeteksi sedini mungkin adanya risiko atau masalah yang terjadi pada kehamilan dan mengetahui perkembangan serta pertumbuhan balita. ${ }^{3}$

Menurut hasil penelitian yang dilakukan oleh Millatin $\mathrm{dkk}$, tenaga kesehatan seperti bidan masih belum maksimal menggunakan buku KIA sebagai media catatan bidan setiap kali ibu datang memeriksakan diri. ${ }^{4}$ Berdasarkan wawancara yang dilakukan oleh peneliti dengan beberapa bidan desa di 2 (dua) puskesmas tentang penggunaan buku KIA, di peroleh informasi bahwa penggunaan buku KIA belum berjalan dengan baik dikarenakan stok buku KIA sering kehabisan. Selain itu, berdasarkan hasil pengamatan didapatkan dari 8 ibu hamil yang memeriksakan kesehatannya di bidan desa hanya 5 yang membawa buku KIA sedangkan lainnya hanya menggunakan buku KMS biasa. Berdasarkan latar belakang diatas menunjukkan bahwa pemenfaatan buku KIA menjadi faktor penghambat bidan desa menggunakan buku KIA sebagai alat catatan perkembangan kesehatan ibu dalam deteksi dini adanya resiko tinggi pada ibu hamil, ibu bersalin dan ibu nifas.

\section{METODE PENELITIAN}

1. Penelitian ini merupakan penelitian kuantitatif dengan metode observasional dan pendekatan cross sectional yang bertujuan untuk mengetahui hubungan dan pengaruh antara variabel independen yaitu persepsi supervisi dan ketersediaan buku KIA terhadap variabel dependen yaitu penggunaan buku KIA dalam pelayanan antenatal oleh bidan desa. Alat ukur dalam penelitian ini adalah kuesioner terstruktur dan lembar observasi penggunaan buku KIA. Populasi pada penelitian ini adalah seluruh bidan desa di Kabupaten Kolaka yang berjumlah 124 orang yang bekerja di 16 wilayah kerja puskesmas se-Kabupaten Kolaka baik di puskesmas pembantu, maupun di polindes. Pengambilan sampel dilakukan dengan metode simple random sampling, didapatkan sebanyak 55 orang yang memenuhi kriteria inklusi dan ekslusi. Analisis bivariat menggunakan analisis produk moment pada variabel persepsi supervisi karena data berdistribusi normal dan analisa sperman's rho untuk variabel ketersediaan buku KIA karena data tidak berdistribusi normal, kemudian dilanjut dengan analisis multivariat dengan uji regresi linear 
HASIL DAN PEMBAHASAN

A. Analisa Univariat

1. Karakteristik Bidan Desa

Tabel 1. Karakteristik Bidan Desa : Umur, Masa Kerja dan Pendidikan Terakhir

\begin{tabular}{llccc}
\hline No & Karakteristik & Jumlah & Presentasi (\%) \\
\hline 1. & Umur & 20-29 tahun & 8 & 14,5 \\
& & 30-39 tahun & 41 & 74,5 \\
& & 40-58 tahun & 6 & 11,0 \\
\hline 2. & Masa Kerja & $1-9$ tahun & 7 & 12,7 \\
& & $10-19$ tahun & 40 & 72,7 \\
& & 20-38 tahun & 8 & 14,5 \\
\hline 3. & Pendidikan Terakhir & Diploma I & 45 & 81,8 \\
& & Diploma III & 10 & 18,2 \\
\hline
\end{tabular}

Berdasarkan tabel 2, terlihat bahwa sebagian besar bidan desa memiliki persepsi supervisi sedang yaitu 33 orang $(60,0 \%)$. Hal ini menunjukkan bahwa bidan desa menginginkan supervisi berjalan sebagaimana mestinya. Kegiatan supervisi yang dilaksanakan oleh Dinas Kesehatan dan puskesmas secara berkala untuk melihat kepatuhan petugas kesehatan, mengidentifikasi masalah dan membantu untuk memecahkan masalah dalam penggunaan buku KIA di lapangan. Prinsip pokok supervisi adalah meningkatkan penampilan bawahan bukan mencari kesalahan bawahan. Pelaksanaan supervisi sebaiknya adalah atasan langsung, supervisi harus dilakukan secara teratur dan berkala, strategi dan tata cara yang akan dilakukan harus sesuai dengan kebutuhan masing-masing bawahan secara individu. ${ }^{4}$

Variabel ketersediaan buku KIA tercantum pada tabel 2. Terlihat bahwa sebagian besar bidan desa menyatakan ketersediaan buku KIA kurang dari jumlah sasaran sebanyak 31 orang (56,4\%). Pengadaaan buku KIA yang dilakukan oleh pemerintah melalui Dinas Kesehatan Provinsi atau Kabupaten/Kota sesuai dengan jumlah ibu hamil dalam setahun ditambah $10 \%$ sebagai "buffer stock". Pendistribusian buku KIA dari Dinas Kesehatan Kabupaten / Kota, ke puskesmas, puskesmas pembantu, polindes dan bidan desa dapat dilakukan 2-4 kali dalam setahun, atau sesuai dengan kebutuhan setempat. ${ }^{3}$

Variabel penggunaan buku KIA dapat dilihat pada tabel 2 yang menunjukkan bahwa sebagian besar bidan desa menggunakan buku KIA dengan kategori sedang yaitu 33 orang $(60,0 \%)$. Untuk melihat kepatuhan bidan dalam menggunakan buku KIA, perlu adanya monitoring dan evaluasi. Hal ini dilakukan untuk menjamin penerapan penggunaan buku KIA sebagai catatan perkembangan kesehatan ibu berjalan dengan baik dan berkualitas.

Salah satu peran bidan desa adalah memberikan buku KIA kepada ibu saat pertama kali melakukan pelayanan antenatal, mengisi buku KIA secara lengkap menyangkut identitas ibu dan anak serta catatan 
kesehatan ibu saat hamil, bersalin dan

melahirkan. ${ }^{5}$

\section{B. Analisa Bivariat}

1.Pengaruh persepsi supervisi dengan penggunaan buku KIA

Tabel. 3 Tabel silang Persepsi

Supervisi dan penggunaan buku KIA oleh bidan desa dalam pelayanan antenatal.

\begin{tabular}{ccccc}
\hline \multirow{2}{*}{$\begin{array}{c}\text { Pesepsi } \\
\text { Supervisi }\end{array}$} & \multicolumn{3}{c}{ Penggunaan Buku KIA } & \multirow{2}{*}{ Total } \\
\cline { 2 - 4 } & Rendah & Sedang & Tinggi & \\
\hline Rendah & $4(44,4 \%)$ & $2(6,1 \%)$ & $2(15,4 \%)$ & $8(14,5 \%)$ \\
\hline Sedang & $5(55,6 \%)$ & $22(66,7 \%)$ & $6(46,2 \%)$ & $33(60,0 \%)$ \\
\hline Tinggi & $0(0,0 \%)$ & $9(27,3 \%)$ & $5(38,5 \%)$ & $14(25,5 \%)$ \\
\hline Total & $9(100,0 \%)$ & $33(100 \%)$ & $13(100 \%)$ & $55(100 \%)$ \\
\hline
\end{tabular}

Berdasarkan tabel 3 terlihat bahwa kategori persepsi supervisi tinggi yang penggunaan buku KIA tinggi (38,5\%), lebih dibanding dengan penggunaan buku KIA sedang dan rendah $(27,3 \%$ dan $0,0 \%$ ). Pembuktian hipotesis adanya pengaruh variabel persepsi supervisi terhadap variabel penggunaan buku KIA. Yang pertama dilakukan uji hubungan dengan menggunakan uji korelasi pearson's R. Hasil uji korelasi diperoleh nilai $r=0,244$ dan nilai $p=0,73$ dimana niai $\mathrm{p}>0,05$ berarti tidak ada hubungan yang bermakna antara persepsi supervisi dengan penggunaan buku KIA dalam pelayanan antenatal. Karena tidak ada hubungan antara variabel persepsi supervisi dengan penggunaan buku KIA maka tidak dilanjutkan ke uji regresi linier. Sehingga dapat disimpulkan bahwa variabel persepsi supervisi tidak berpengaruh secara bermakna terhadap penggunaan buku KIA dalam pelayanan antenatal oleh bidan desa di Kabupaten Kolaka.

Berdasarkan hasil penelitian, kemungkinan penyebab supervisi tidak berhubungan dengan penggunaan buku
KIA adalah penggunaan buku KIA dalam pemeriksanaan antenatal tergantung dari individu yang melakukan kegiatan tersebut artinya apabila individu tersebut tidak menggunakan buku KIA walaupun di laksanakan supervisi, tetap tidak akan dilaksanakan dengan baik. Supervisi merupakan salah satu sistem manajemen pengawasan dari atasan yang bertujuan memberi bantuan pada bawahan secara langsung sehingga bawahan melaksanakan tugas sesuai dengan harapan. ${ }^{6}$

Penelitian ini sejalan dengan penelitian yang dilakukan oleh Tri Anasari bahwa persepsi supervisi tidak berhubungan dengan kelengkapan pengisian buku KIA dikarenakan pengisian buku KIA tergantung dari bidan yang melakukan kegiatan tersebut artinya apabila bidan tersebut tidak melakukan pengisian buku KIA walaupun supervisi dari atasan tetap tidak akan dilaksanakan dengan baik. ${ }^{7}$ Berdasarkan penelitian yang dilakukan oleh Haris Basuni (2019), disebutkan bahwa tidak ada hubungan yang signifikan antara variabel supervisi dengan persepsi praktik perawat dalam 
pelaksanaan universal precaution

pencegahan infeksi. ${ }^{8}$

Namun, penelitian ini bertolak belakang dengan penelitian yang dilakukan oleh Millatin (2017) yang menyebutkan bahwa terdapat hubungan antara supervisi pimpinan tempat bekerja dengan kinerja bidan dalam pemanfaatan buku KIA. Supervisi merupakan pengamatan secara langsung dan berkala oleh atasan terhadap pekerjaan yang dilaksanakan oleh bawahan yang kemudian akan ditemukan masalah, segera diberikan petunjuk atau pengarahan secara langsung untuk mengatasi. Supervisi merupakan rangkaian yang dilakukan secara berkala dan berkesinambungan meliputi pemantauan, pembinaan, dan pemecahan masalah serta tindak lanjut. Pelaksanaan supervisi oleh kepala puskesmas dan bidan koordinator diharapkan akan memperbaiki kinerja bidan desa karena pelaksanaan supervisi yang baik, tidak hanya di akhir kegiatan tetapi di awal dan ketika proses masih berlangsung. ${ }^{4}$ Selain itu, berdasarkan penelitian yang dilakukan oleh Natiqotul (2015) disebutkan bahwa supervisi mempunyai hubungan yang signifikan dengan kepatuhan bidan dalam mendeteksi preeklampsia. $^{9}$ 
2. Pengaruh ketersediaan buku KIA dengan penggunaan buku KIA

Tabel. 4 Tabel silang Ketersediaan dan penggunaan buku KIA oleh bidan desa dalam pelayanan antenatal. pertama kali datang memeriksakan kehamilanya selama ada persediaan dan jika stok habis, bidan desa akan mengganti buku KIA dengan KMS biasa.

\begin{tabular}{ccccc}
\hline \multirow{2}{*}{ Kesersediaan Buku KIA } & \multicolumn{2}{c}{ Penggunaan Buku KIA } & \multirow{2}{*}{ Total } \\
\cline { 2 - 4 } & Rendah & Sedang & Tinggi & \\
\hline Kurang dari jumlah & $7(77,8 \%)$ & $17(51,5 \%)$ & $7(53,8 \%)$ & $31(56,4 \%)$ \\
sasaran & & & & \\
\hline Sesuai jumlah sasaran & $2(22,2 \%)$ & $16(48,8 \%)$ & $6(46,2 \%)$ & $24(43,6 \%)$ \\
\hline Total & $9(100 \%)$ & $33(100 \%)$ & $13(100 \%)$ & $55(100 \%)$ \\
\hline
\end{tabular}

Berdasarkan tabel 4 terlihat bahwa ketersediaan buku KIA kurang dari jumlah sasaran yang menggunakan buku KIA, yang sebagian besar memiliki kategori rendah sebesar $77,8 \%$, sedangkan penggunaan buku KIA dengan kategori sedang dan tinggi sebanyak 51,5\% dan 53,8\%. Pembuktian hipotesis adanya pengaruh variabel ketersediaan buku KIA terhadap variabel penggunaan buku KIA. Yang pertama dilakukan uji hubungan dengan menggunakan uji korelasi spearman,s Rho. Hasil uji korelasi diperoleh nilai $r=0,157$ dan nilai $p=0,25$ dimana nilai $p>0,05$ yang berarti tidak ada hubungan yang bermakna antara ketersediaan buku KIA dengan penggunaan buku KIA dalam pelayanan antenatal.

Dikarenakan tidak ada hubungan antara variabel ketersediaan buku KIA dengan penggunaan buku KIA maka tidak dilanjutkan ke uji regresi liner. Sehingga dapat disimpulkan bahwa variabel ketersediaan buku KIA tidak berpengaruh secara bermakna terhadap penggunaan buku KIA dalam pelayanan antenatal oleh bidan desa di Kabupaten Kolaka. Hal ini mungkin dikarenakan dalam penyusunan dan pendistribusian buku KIA dilaksanakan oleh Dinas Kesehatan Provinsi yang disalurkan melalui Dinas Kabupaten yang sering tersendat sehingga penyaluran ke bidan desa kurang. Namun, bidan desa tetap memberikan buku KIA pada ibu hamil yang
Penelitian ini sejalan dengan penelitian yang dilakukan oleh Anasari (2013), yang menyebutkan bahwa tidak ada hubungan antara kelengkapan sarana dengan pengisian buku KIA oleh bidan dalam deteksi dini risiko tinggi yang dapat terjadi pada ibu hamil. Kelengkapan sarana pelayanan merupakan salah satu faktor pendukung yang seharusnya tidak terlupakan. ${ }^{10}$

Komitmen dan peran bidan desa dan bidan puskesmas dalam mengisi buku KIA dengan lengkap seperti identitas ibu dan anak, catatan kesehatan ibu saat hamil, bersalin dan melahirkan sangat diperlukan. Selain itu, juga perlu dilakukan pencatatan kesehatan bayi dan anak menggunakan Kartu Menuju Sehat (KMS), catatan perkembangan anak, catatan imunisasi dan pemberian vitamin, catatan penyakit yang diderita anak balita serta perkembangan anak balita. ${ }^{11}$ Hal ini bertujuan untuk mewujudkan kemandirian keluarga dalam memelihara kesehatan ibu dan anak dan menjadi salah satu upaya program dalam meningkatkan penggunaan buku KIA. ${ }^{12}$

\section{KESIMPULAN}

Berdasarkan hasil penelitian dapat disimpulkan bahwa variabel persepsi supervisi tidak berpengaruh secara bermakna terhadapa penggunaan buku KIA dalam pelayanan antenatal oleh bidan desa di Kabupaten Kolaka. Selain itu, variabel 
ketersediaan buku KIA tidak berpengaruh secara bermakna terhadap penggunaan buku KIA dalam pelayanan antenatal oleh bidan desa di Kabupaten Kolaka. Dinas Kesehatan dan puskesmas sebaiknya melakukan supervisi dan evaluasi secara berkala ke bidan desa tentang pelayanan antenal khususnya pada mengisi buku KIA dalam deteksi dini risiko tinggi ibu hamil dilakukan secara lengkap sesuai dengan buku pedoman pengisian buku KIA. Dinas Kesehatan sebaiknya melakukan penggandaan buku KIA sesuai dengan jumlah sasaran ibu hamil dan pendistribusian yang berkesinambungan agar terjamin ketersediaan buku KIA di bidan desa serta kelengkapan fasilitas pendukung lainnya dalam deteksi dini risiko tinggi ibu hamil.

\section{UCAPAN TERIMA KASIH}

Ucapan terimah kasih kami sampaikan kepada : Kepala Dinas Kesehatan Kabupaten Kolaka yang telah memberi izin penelitian dan bidan desa yang bersedia menjadi responden.

\section{DAFTAR PUSTAKA}

2. Kementerian Kesehatan RI. Profil Kesehatan Indonesia Tahun 2017. Terbit Kementerian Kesehatan RI. Jakarta. 2018.

3. Dinkes Kabupaten Kolaka. Profil Kesehatan Kabupaten Kolaka tahun 2018. http://dinkes.

Kolakakab.go.id/. 2019.

4. Departemen Kesehatan RI. Petunjuk Teknis Penggunaan Buku KIA. Penertit, Depkes JICA Jakarta. Cetakan tahun 2016.

5. Millatin P, Pedvin Ratna M, Yuyun M. Analisis kinerja dalam pemanfaatan buku KIA oleh bidan di puskesmas Kabupaten Pekalongan. Kajen Vol. 01 No. 01 $2017: 15-24$
6. Colti Sistiarani, Elviera G, Dyah U. P. Fungsi Pemanfaatan Buku KIA terhadap Pengetahuan Kesehatan Ibu dan Anak pada Ibu. Kesmas, Jurnal Kesehatan Masyarakat Nasional Vol. 8, No. 8, Mei 2014.

7. Yudhy D, Putri A Wigati, Fifi Dwijayanti. Kinerja Petugas Dalam Pencatatan Dan Pelaporan PWS KIA Di Puskesmas Duren. Jurnal Kesehatan Masyarakat KEMAS 10 (2) (2015)

8. Tri Anasari. Faktor-Faktor Yang Mempengaruhi Kelengkapan

Pengisian Buku KIA Oleh Bidan Dalam Deteksi Dini Risiko Tinggi Kehamilan Di Puskesmas Kabupaten Banyumas Tahun 2012 ejournal.stikesmuhgombong.

ac.id/index.php/JIKK/article/2013

9. Haris Basuni, Chriswardani S, Sri Achadi N. Faktor-Faktor Yang Berpengaruh Terhadap Praktik Perawat Dalam Pelaksanaan Universal Precaution Di RSUD Brebes. Jurnal Manajemen Kesehatan Indonesia Volume 7 Nomor 2 Agustus 2019

10. Natiqotul Fatkhiyah. Motivasi, Kualitas Supervisi dan Kepatuhan Bidan dalam Mendeteksi Preeklampsia. Jurnal Kesehatan Masyarakat KEMAS 10 (2) (2015) 195-202

11. Suharmiati, Lestari Handayani, et.al. Studi penilaian motivasi dan komitmen bidan puskesmas dalam pemanfaatan buku pedoman KIA di indonesia (studi kasus di kota batu, kabupaten cianjur dan Kabupaten Belitung Timur). Buletin Penelitian Sistem Kesehatan - Vol. 18 No. 4 Oktober 2015: 355-363

12. Colti Sistiarani, Elviera G., Bambang H. Analisis kualitas penggunaan buku kesehatan ibu 
anak. Jurnal Kesehatan Masyarakat. KEMAS 10 (1) (2014) 14 - 20

13. Nita Farida. Determinan pemanfaatan buku kesehatan ibu dan anak (KIA) oleh ibu hamil di
Puskesmas Wanakerta Kabupaten Karawang. The Southeast Asian Journal of Midwifery Vol. 2, No.1, Oktober 2016, Hal: 33-41 